\title{
References
}

Dueholm, K. S. 1979: Geological and topographic mapping from aerial photographs. Medd. Inst. Surv. Photogrammetry, Danm. Tekn. Højsk. 10, 204 pp.

Jepsen, H. F. \& Dueholm, K. S. 1978: Computer supported geological photointerpretation. Rapp. Grønlands geol. Unders. 90, 146-150.

Pedersen, S. A. S. 1981: The application of computer-assisted photogrammetric methods in the structural analysis of part of the North Greenland Fold Belt. J. Struct. Geol. 3, 253-264.

K. S. D., Instituttet for Landmåling og Fotogrammetri, Danmarks Tekniske Højskole, Landmålervej 7 , DK-2800 Lyngby, Denmark.

\section{Malene stratigraphy and late Archaean structure: new data from Ivisârtoq, inner Godthåbsfjord, southern West Greenland}

\author{
Brian Chadwick
}

This report summarises the principal results of a six-week study of some critical areas in Ivisârtoq (part of the Ivisârtoq region, 65 V. 2 Nord; fig. 1) by a two-man expedition (the writer and his undergraduate assistant) during the summer of 1985, a period of exceptionally good weather. Our objective was to complete the field programme of a team from the University of Exeter (Chadwick et al., 1983; Brewer et al., 1984) which had been seriously disrupted by bad weather in 1983 . The main thrust of the field work in 1985 was to investigate the geometry of the late Archaean system of domes of gneisses and intervening synclinal cusps of Malene supracrustal rocks which dominates the structure of Ivisârtoq (figs 1,2). The field mapping revealed important new details, not only of the structure but also of the Malene stratigraphy and the emplacement of granitic and basaltic magmas during the development of the system of domes and synclines.

Systematic geological investigations in the Ivisârtoq region began in 1976 (Allaart et al., 1977 ) and important contributions have been made by Hall \& Friend $(1979,1983)$, Hall $(1980,1981)$ and Friend et al. (1981). Some preliminary results of investigations by the Exeter team have been reported by Brewer et al. (1984), Chadwick (1985), and Coe \& Robertson (1984). Details of isotopic ages and petrogenesis of the gneisses and late Archaean granites have been reported by Robertson (1985, in press).

\section{Malene stratigraphy}

The most complete section of the Malene stratigraphy is preserved in the southern limb of the asymmetric syncline in southern Ivisârtoq (figs $1,2,3,4$ ). The attenuation of the stratigraphy on the northern limb (fig. 3) may be an effect of rapid variation in the original thick- 


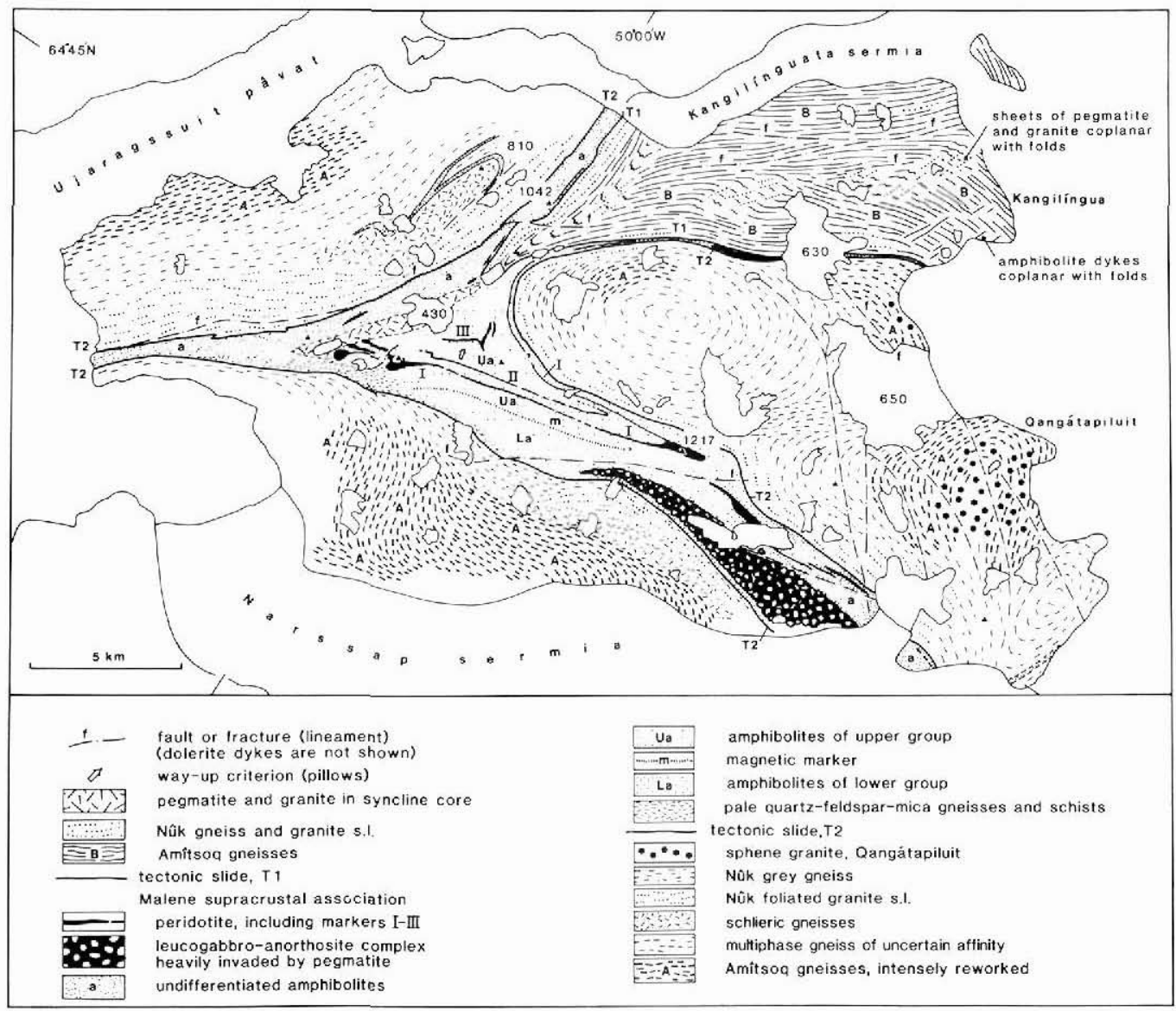

Fig. 1. Outline lithological map of Ivisärtoq. MD dykes are not shown and certain large bodies of pegmatite within the Malene outcrop are omitted for reasons of clarity.

ness of the volcanic pile, or it may be the result of thinning or slicing of the succession on low-angle slides (T1,T2; figs 2,3) related to early horizontal tectonic interleaving.

The section of the stratigraphy on the southern limb (fig. 4) is dominated by variably deformed amphibolites, many of which preserve pillow structures. The amphibolites in central southern Ivisârtoq may be subdivided into a younger and an older group separated by a thin $(c .10 \mathrm{~m}$ ), but important, marker (figs 1,4$)$ of calc-silicate rocks and pale grey-green chloritic schists locally with a small-scale lenticular structure suggesting that the original assemblage included lapilli tuffs. The marker is commonly rich in disseminated fine-grained magnetite. Disseminated sulphides, mostly pyrite but including chalcopyrite, are common in some parts of the marker. The marker has been traced over a strike length of $7 \mathrm{~km}$ (fig. 1), but its significance was not recognised until late in the mapping programme and it may persist further to the east. The distinction between the two major groups of amphibolites elsewhere in Ivisârtoq requires further, more detailed mapping. All the lithologies in the Malene sequence 


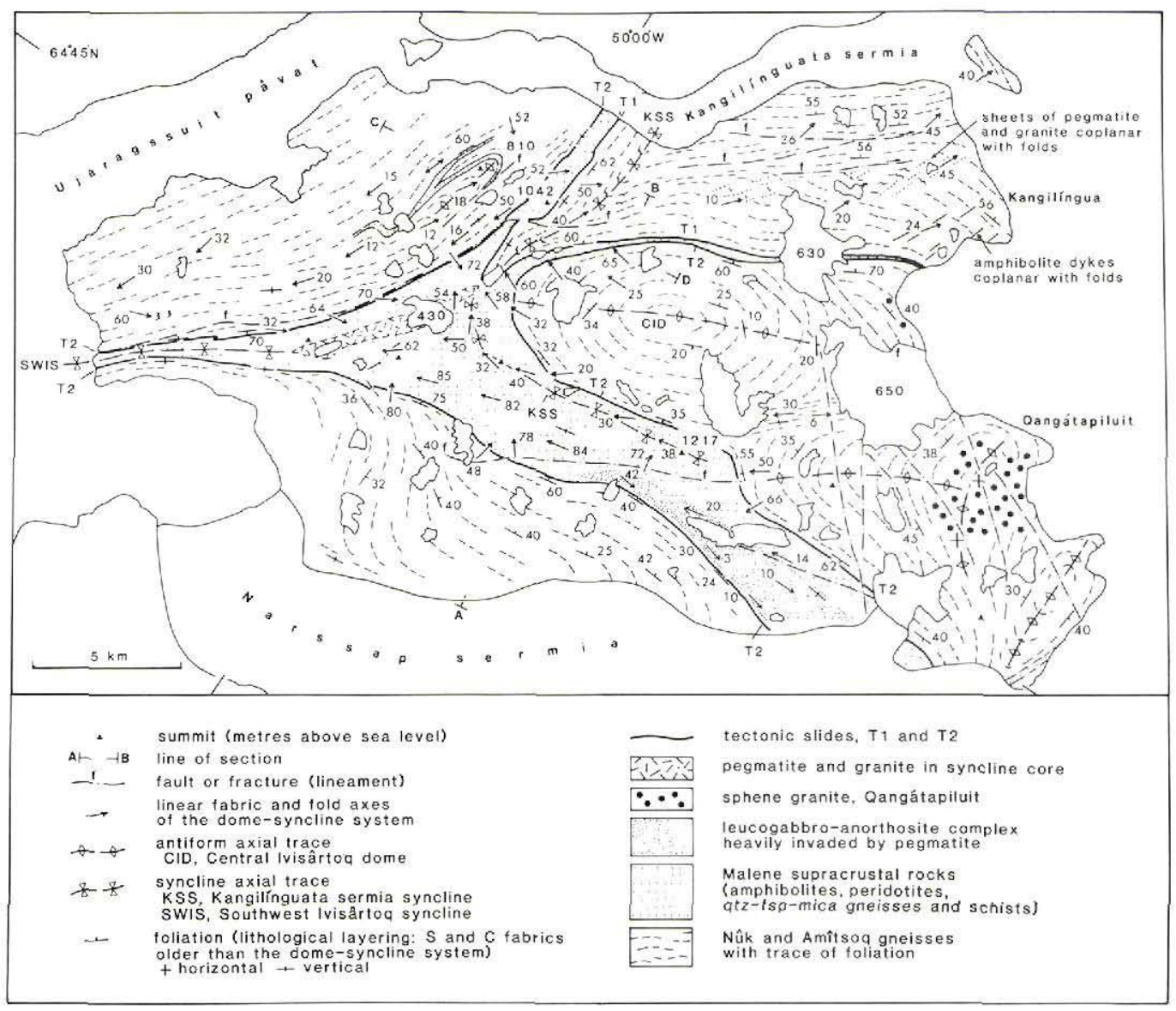

Fig. 2. Outline map of the structure of Ivisârtoq.

in Ivisârtoq have been pervasively metamorphosed to high grade (Hall, 1981), but effects of retrogression to low-grade assemblages are common, being most intense adjacent to faults.

The younger group of amphibolites which overlies the magnetite-rich marker (figs 1,3,4) is characterised by variably deformed pillow structures with locally abundant diopside and epidote. Cores of pillows are commonly replaced by assemblages rich in diopside and epidote, and discordant skarns of diopside-epidote-garnet-carbonate are evident on many outcrops. Skarns up to $10 \mathrm{~m}$ thick with sheets of impure grey marble are locally prominent in the amphibolites immediately above the magnetite-rich marker and elsewhere. Pillow structures are also relatively common in ultramafic amphibolites in the younger group. These ultramafic amphibolites are similar to those with komatiitic composition reported by Hall (1980). This type of amphibolite is common in south Ivisârtoq and it appears that komatiites may have played a more significant role in the Malene volcanism than has been evident hitherto. In some instances the pillow structures in the tholeiitic (Hall, 1981) and komatiitic amphi- 

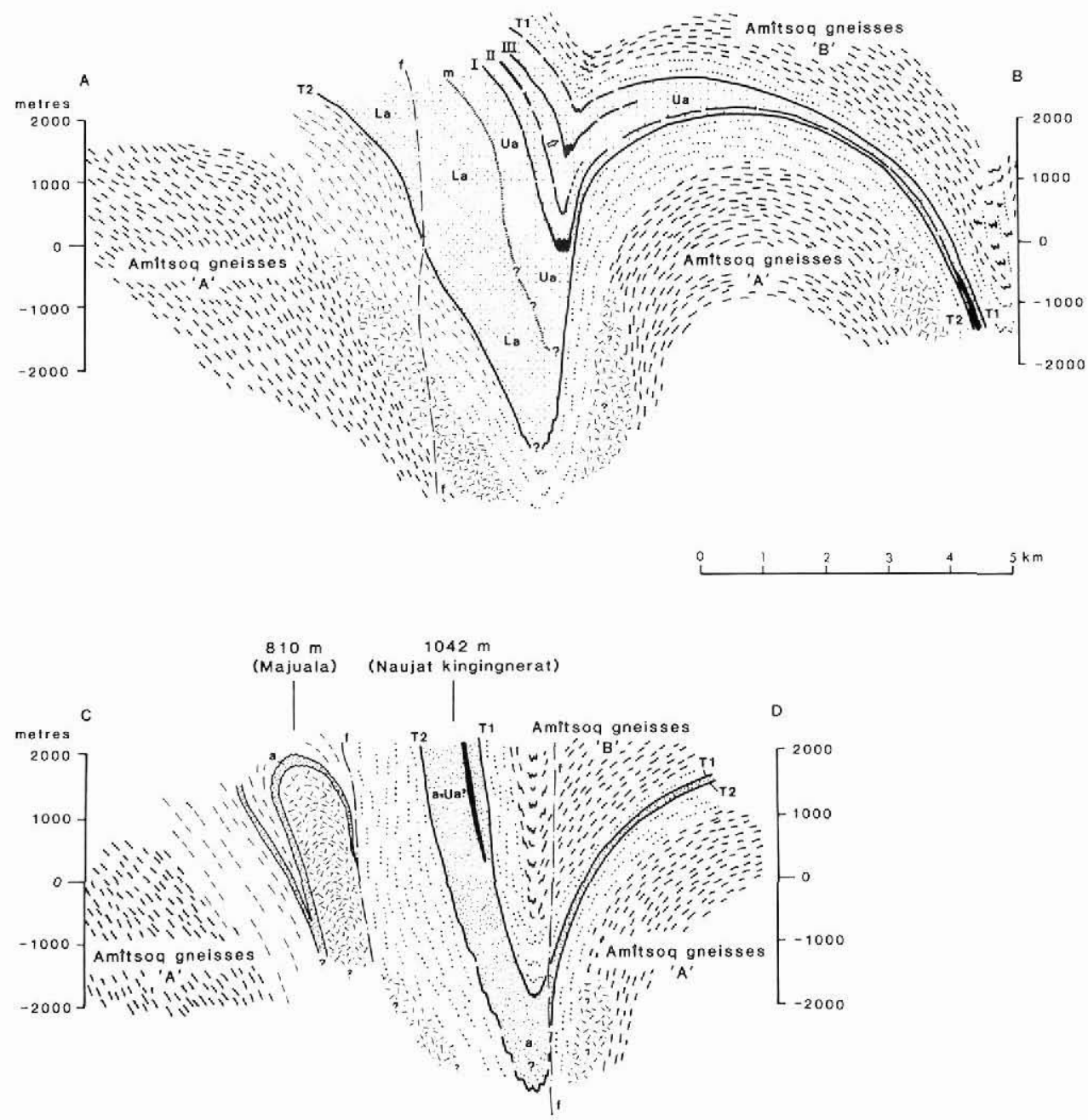

Fig. 3. Sections illustrating the structure of Ivisârtoq. Lines of sections are shown in fig. 2. Legend as fig.1.

bolites reveal the stratigraphic sequence, but most are too deformed to be useful as indicators of way-up.

Sheets of metamorphosed peridotite rich in olivine and tremolite are common in the younger group of amphibolites. Three principal sheets (I-III, fig. 1) form valuable structural markers traceable along strike for many kilometres, commonly as trains of large boudins up to $600 \mathrm{~m}$ long separated by necks of pegmatite or pillowed amphibolite. Their persistence along strike is remarkable because the sheets are rarely thicker than $50 \mathrm{~m}$ except in the cores of regional folds where they form large mullions, for example in the area of the $1217 \mathrm{~m}$ summit.

Contacts with the pillowed amhibolites are sharp, in some instances with seams of impure marble at the base of the sheets (fig. 4), or they are sheared with development of dark green 


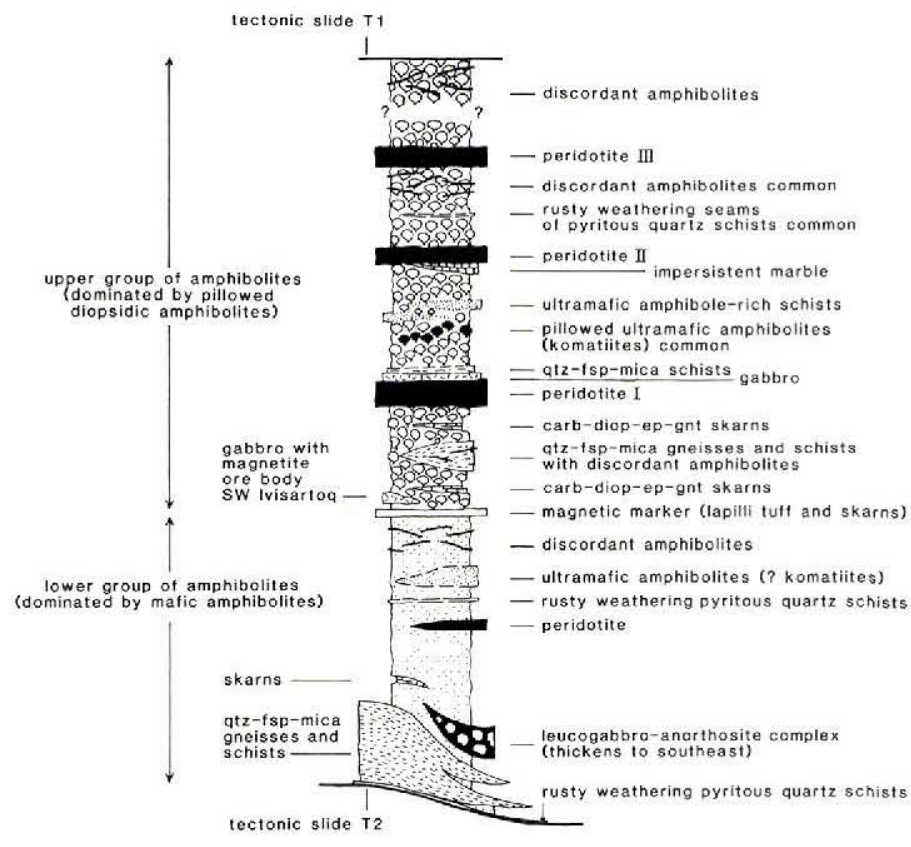

thin discordant sheets of gabbroic and other amphibolites

are common at most levels within the Malene sequence

Fig. 4. Schematic representation of a section of the Malene stratigraphy in central southern Ivisârtoq. The section is not to scale and the thickness of peridotites and other lithological units are exaggerated or reduced. The total thickness of the section is in the order of $3 \mathrm{~km}$, but effects of deformation suggest its original thickness may have been at least $5 \mathrm{~km}$.

chlorite-amphibole schists. The sheets locally grade up into gabbro with a distinctive spotty texture of small aggregates of hornblende prisms set in a feldspathic matrix. This type of gabbro persists for long distances at the top of peridotite 1 (figs 1,4). Differentiation into gabbro and the presence of small mushroom-shaped apophyses of gabbro at the top of some sheets confirm previous suggestions that the peridotites were intruded as sills (Brewer et al., 1984). Some of the thin gabbros at the top of the peridotite sheets are overlain by $2-3 \mathrm{~m}$ of rusty pyritous quartz-mica-feldspar schists, a relation suggesting that magmatic injection was controlled by a pre-existing sheet of sediment. Field evidence for an intrusive origin is at variance with the textures and Mg-rich composition of olivine in similar Malene peridotites elsewhere in the Ivisârtoq region which led Crewe (1984) to suggest that the peridotites were mantle residua, a view similar to that of Friend \& Hughes (1978) who concluded that certain spinel-bearing peridotites in pillowed amphibolite at Ravns Storø may represent tectonically emplaced portions of upper mantle. The field evidence in Ivisârtog cannot be reconciled with tectonic emplacement but it raises important issues concerning the temperature and composition of the injected magmas.

Whilst gabbro occurs as a differentiate at the top of some sheets of peridotite, it is more 
common as low-angle sheets within the pillowed amphibolites of both groups. These sheets are relatively thin $(10-30 \mathrm{~m})$, but larger lenticular bodies, perhaps thickened tectonically, are found locally. One of these lenticular bodies in south-west Ivisârtoq contains a widespread concentration of fine-grained magnetite disseminated in a matrix of green amphibole: metamorphic reaction has locally given rise to coarse garnet cored by magnetite. Most of the gabbros are medium grained with a spotty texture formed by small aggregates of hornblende set in a matrix dominated by plagioclase. The aggregates are commonly elongated parallel to axes of folds parasitic on the regional syncline (KSS, fig. 2). The gabbros are mafic, but some are pale with plagioclase more abundant than hornblende. Some of the thinner sheets of gabbro contain aggregates of plagioclase variably altered to epidote. In a few instances the aggregates contain interstitial hornblende suggesting they are xenoliths of anorthosite or leucogabbro. The aggregates are abundant in some sheets and may be concentrated in the lower part. Similar aggregates are common in discordant amphibolites lacking the spotty texture. Many of these amphibolites are similar in appearance to the $C$ Ameralik dykes (Chadwick, 1981) which characterise the Amitsoq gneisses. Discordant relations show that some of these amphibolites and gabbros are younger than the sheets of peridotite, although they are all presumed to be related genetically to the Malene volcanism.

Amphibolites of the older group below the magnetic marker are more mafic than those above. Deformation is also more intense in the older group and consequently primary structures are less distinct. In a few instances relics of pillow structure are discernible and pillow breccias appear to be common in parts of the group immediately below the magnetic marker. Ultramafic schists rich in amphibole are prominent in parts of the older group, but olivine-tremolite peridotites, common in the younger group, are rare. Calc-silicate-rich and carbonate-rich skarns are also less common in the older group. The group wedges out to the west into pale quartz-feldspar-mica gneisses and schists, but its distribution to the east and elsewhere in Ivisârtoq remains to be determined by detailed mapping.

A major body of leucogabbro with minor anorthosite and melagabbro lies within the Malene amphibolites in south-east Ivisârtoq. It tapers to the west, ending in a train of thin lenses. The leucogabbro and the adjacent host amphibolites are severely disrupted by abundant pegmatites with subordinate granite, but there is little or no relative rotation of adjacent blocks. The leucogabbro is identical in the field to leucogabbro-anorthosite complexes elsewhere in the Godthåbsfjord region which are characterised by coarse megacrysts of plagioclase set in a plagioclase-hornblende matrix. Sorting of the megacrysts in the Ivisârtoq leucogabbro has locally given rise to a primary layering, but primary textures are variably deformed, feldspars commonly being elongated parallel to the regional mineral lineation (fig. 2). In contrast the ramifying system of muscovite pegmatites is not deformed, although it is believed to be related to a late period of tectonic disruption during the evolution of the domes and synclines. Dark mica is relatively common in the leucogabbro and may be related to LIL metasomatism associated with injection of the pegmatites. Gabbroic amphibolites which commonly overlie the leucogabbro complex may be an integral part of the lower group of amphibolites or they may be differentiates derived from the complex itself. The complex is underlain by a thin screen of heavily agmatised amphibolite and garnetiferous gneiss which is continuous along strike with the lower group of amphibolites to the west. The screen is in turn underlain by homogeneous grey gneisses regarded as Nûk gneisses. The leucogabbro complex is regarded as part of a differentiated body derived, like the Fiskenæsset anorthosite complex, from a basaltic parental magma (Weaver et al., 1981) intruded in the 
form of a large laccolith into the Malene volcanic pile. There is no evidence in the host rocks to suggest that intrusion and differentiation took place at deep crustal levels.

Pale, locally micaceous, amphibolite dykes are common in parts of the higher levels of the leucogabbro. Some containing feldspar crystals detached from the immediately adjacent host leucogabbro are similar to dykes reported by Brewer et al. (1984) from the presumed continuation of the Ivisârtoq leucogabbro south-east of Narssap sermia. Parts of the upper levels of the leucogabbro are also cut by low-angle sheets (c. $1 \mathrm{~m}$ thick) of grey, mediumgrained biotite schist.

Pale grey-brown, medium-grained quartzofeldspathic gneisses and schists are prominent west of the lower group of amphibolites in south-west Ivisârtoq (figs 1,4) where they reach a maximum thickness of about $500 \mathrm{~m}$. Similar gneisses and schists occur as extensive lenticular sheets, or as thin seams elsewhere within the amphibolites of both groups. Some of these thin seams are rich in quartz and have a distinctive orange weathering consequent on the abundance of sulphides, especially pyrite. Quartz, plagioclase, biotite and muscovite dominate the compositions of the gneisses and schists, but pale brown amphibole, cordierite (commonly replaced by pinite), microcline and garnet are abundant locally. Accessory minerals include tourmaline, zircon, apatite, allanite, pyrite, chlorite, staurolite and sillimanite. Compositional banding and a small-scale lenticular structure in some of the gneisses and schists are probably primary bedding phenomena, but other primary structures such as grading and cross-bedding were not seen. The gneisses and schists are commonly host to low-angle sheets of amphibolite, including gabbro. The pale gneisses and schists are similar to the suite of leucocratic schists in the Ravns Storø Group near Fiskenæsset (Friend, 1976), but they include only a few examples of lithotypes comparable with the metasedimentary gneisses typical of the Malene rocks of north-west Buksefjorden (Beech \& Chadwick, 1980). The gneisses in north-west Buksefjorden were interpreted as detrital sediments with admixtures of Mg-rich clay minerals, but an acid-intermediate pyroclastic origin is favoured for most of the gneisses and schists in Ivisârtoq. Some of the thicker units may include deformed dacitic or rhyolitic flows. Investigations of the mineralogy and chemistry are in hand.

\section{Structure}

The interpretation of the structure of Ivisârtoq in terms of a system of contemporaneous domes and synforms reported by Brewer et al. (1984) and Chadwick (1985), as opposed to a system of superimposed folds (Hall \& Friend, 1979), has received further support from data collected in 1985 . The domes and synforms were superimposed on a flat-lying complex of tectonically interleaved sheets of Malene supracrustal rocks and Amîtsoq gneisses (Hall \& Friend, 1979), the upper boundary of the principal Malene sheet in Ivisârtoq being interpreted as a tectonic slide (T1; figs 1,2 ) by Chadwick (1985). Whilst recognition of new details of the Malene stratigraphy has been of special importance in revealing the hitherto unknown asymmetry and extent of the syncline in the south of Ivisârtoq (KSS, figs 2,3), greater significance attaches to a new interpretation of the gneisses in south Ivisârtoq and Qangátapiluit.

Hall \& Friend (1979, 1983), Brewer et al. (1984) and Chadwick (1985) were of the opinion that the gneisses in the Central Ivisârtoq dome, in Qangátapiluit and in the south of Ivisârtoq were all of Nûk affinity, although the presence of enclaves of Amîtsoq gneisses in the east of Qangátapiluit is indicated by Hall (1981) and Hall \& Friend (1983). This view was 
supported by interpretations of the isotope geochemistry of Nûk gneisses in the south-east of the Ivisârtoq region which implied that Amitsoq gneisses were not present at low structural levels, i.e. below the principal Malene sheet in Ivisârtoq (Robertson, 1985, in press). However, mapping in 1985 has revealed widespread tracts of multiphase gneisses with pods of amphibolite locally containing feldspar aggregates typical of $C$ Ameralik dykes. Enclaves characteristic of the Akilia association are lacking, but on the grounds of the occurrence of what are presumed to be severely disrupted relics of Ameralik dykes, the gneisses are regarded as Amîtsoq (fig. 1). In south Ivisârtoq these gneisses pass locally into schlieric gneisses which in turn may be traced up into foliated, homogeneous grey granite sensu lato (fig. 1). Comparable sequences occur in parts of Qangátapiluit and within the Central Ivisârtoq dome (figs 1,2), but they have not been examined in detail, and the affinity of much of the multiphase gneiss in these areas remains equivocal. Transitions from Amitsoq gneiss to granitic gneiss similar to those in south Ivisârtoq (labelled Nûk foliated granite sensu lato; fig. 1) are known from Kangilíngua (Chadwick et al., 1983; Hall \& Friend, 1983) where the granitic derivative (Ivisârtoq granite gneiss) has yielded isochron ages of $2753 \pm 41 \mathrm{Ma}$ (Rb$\mathrm{Sr}$ ) and $2543 \pm 300 \mathrm{Ma}(\mathrm{Pb} / \mathrm{Pb})$ (Robertson, 1985, in press). Robertson reported that the $\mathrm{Rb}-\mathrm{Sr}$ age is within error of the age of high-grade metamorphism of the Nûk gneisses in the Ivisârtoq region and it may indicate the time of partial melting, whilst the $\mathrm{Pb} / \mathrm{Pb}$ age may indicate homogenisation of $\mathrm{Pb}$ isotopes at the time of emplacement of the Qorqut granite complex. Because the Ivisârtoq granite gneiss is deformed by the dome-synform structures, it follows that the system of domes and synforms may be younger than $c .2750 \mathrm{Ma}$. Robertson (in press) has suggested that the system may have developed during the interval c. 2650-2600 Ma.

Hall \& Friend (1979) interpreted much of the multiphase gneisses in the west of Ivisârtoq as Amitsoq on the grounds of isotopic age data and the presence of Ameralik dykes on the coast of Ujaragssuit pâvat. Their interpretation was challenged by Chadwick (1985) on the grounds that the isotopic age data were ambiguous and essential field criteria characteristic of the Amîtsoq gneisses were lacking in the gneisses inland. However, V. R. McGregor and A. P. Nutman (personal communication, 1985) have also recognised discordant Ameralik dykes and enclaves of Akilia rocks in coast outcrops of Ujaragssuit pâvat, confirming the presence of Amitsoq gneisses below the principal Malene sheet in the west. The position of these gneisses at this structural level is consistent with the new interpretation of the multiphase gneisses in the Central Ivisârtoq dome, in Qangátapiluit and in south Ivisârtoq. It is also consistent with an interpretation of the $\mathrm{Rb}-\mathrm{Sr}$ and $\mathrm{Pb} / \mathrm{Pb}$ isotope geochemistry of Nûk gneisses in Nunatarssuaq, the area south of Narssap sermia (fig. 1), which suggests that they were contaminated by $\mathrm{Pb}$ from Amîtsoq gneisses occupying structural levels lower than those in south Ivisârtoq (M. A. Brewer, personal communication, 1985). This interpretation is at variance with that proposed by Robertson (1985, in press) for Nûk gneisses elsewhere in the Ivisârtoq region, but discussion of the reasons for these conflicting views is not appropriate here.

If the multiphase gneisses in south Ivisârtoq are Amitsoq, it follows that the original lower boundary of the principal Malene sheet was either a tectonic slide like the upper boundary or it was an unconformity. Grey gneisses of presumed Nûk (and younger?) affinity intervene between the Malene sheet and the underlying Amîtsoq gneisses (figs 1,3), but because enclaves of Malene rocks are rare or absent in the grey gneisses, the lower boundary of the Malene sheet in south Ivisârtoq must mark the original contact of the Malene rocks with the 
Amîtsoq gneisses, although pegmatite injections, hydrothermal effects and faulting have obscured details of its primary characteristics. In the absence of unambiguous evidence for an unconformity, the original contact is regarded as a tectonic slide like the upper boundary. This interpretation of the lower boundary in south Ivisârtoq has been extended to the rest of the contact in Ivisârtoq and it is labelled T2 (figs 1,2,3). In south-east Kangilíngua the Nûk gneisses below the contact contain abundant enclaves of banded amphibolite and hence the present Malene boundary may not coincide with the original slide T2. Most of the Nûk or younger granitic gneisses, including the Ivisârtoq granite gneiss, are concentrated either immediately above the slide $\mathrm{T} 1$ or immediately below the slide T2 (figs 1,3).

Amîtsoq gneisses above the slide T1 in Kangilíngua contain unambiguous discordant Ameralik dykes and abundant enclaves of Akilia amphibolites, peridotites, and metamorphosed banded iron formations in marked contrast to the presumed Amîtsoq gneisses below the slide $\mathrm{T} 2$ which are characterised only by scattered pods of amphibolite (no discordances) of $C$ Ameralik dyke type, although Akilia enclaves have been reported from coastal outcrops in the west (V. R. McGregor \& A. P. Nutman, personal communication, 1985). The higher level, unambiguous Amîtsoq gneisses, here labelled Type 'B', are thus distinct from those labelled Type ' $A$ ' at the lower tectonic level (figs 1,3). This difference is compatible with the Amîtsoq gneisses above and below the Malene sheet having been brought together from widely different areas by the tectonic interleaving. The directions and magnitudes of the displacements on the slides $\mathrm{T} 1$ and $\mathrm{T} 2$ are unknown, although the persistence of $\mathrm{T} 1$ elsewhere in the Ivisârtoq region (Chadwick, 1985) suggests displacements were of the order of tens of kilometres. The presence of Ameralik dykes in Amitsoq gneisses ' $A$ ' and ' $B$ ' indicates that the original dyke swarm was widespread, but the lack of enclaves in Type ' $B$ ' suggests the Akilia association had a more restricted distribution.

$S$ fabrics in the Malene amphibolites and Nûk gneisses in Ivisârtoq have been described in terms of flattening or oblate strain phenomena believed to have developed during the period of tectonic interleaving (Chadwick, 1985). Other fabrics have been recognised in 1985 in the leucogabbro complex in south-east Ivisârtoq. Primary textures of feldspar are variably deformed with rapid changes in grain size taking place over small distances $(c .1 \mathrm{~cm})$ in smallscale anastomosing shear zones broadly parallel to the regional $S$ fabric and lithological boundaries in adjacent Malene rocks. This style of deformation in the leucogabbro complex has given rise to a coarse planar fabric similar to $C$ fabrics in mylonites (Berthé et al., 1979), $C$ referring to 'cisaillement' or localised high-strain shear planes (Simpson, 1985). Least deformed parts of the leucogabbro survive in coarse pods or augen between the high strain zones. $S$ fabrics (i.e. fabrics with the schistosity related to the shape principal finite strain plane $X Y(X>Y>Z)$ indicated by deformed pillows, augen, etc.) in the Malene rocks and younger gneisses are folded by the dome-synform structures, although it appears that these fabrics were enhanced on the steep limbs of these structures during this period of deformation. The relation between dome-synform structures and the $C$ fabric in the leucogabbro complex is not clear, although the fabric probably formed at the same time as the $S$ fabric in the adjacent rocks.

Feldspars in the leucogabbro are variably elongated parallel to the regional mineral lineation coaxial with folds of the dome-synform system, the lineation being intense in the synforms and weak or absent in the domes. The linear fabric is best seen in the Malene rocks as a preferred orientation of amphiboles and in the Amitsoq gneisses as a quartz-feldspar rodding. Elongation of feldspar primocrysts in the leucogabbro complex, feldspar aggregates in 
Ameralik dykes and Malene discordant amphibolites and pillows in Malene amphibolites show that the lineation is a shape finite maximum extension direction. The lineation and coaxial dome-synform folds have variable plunge (fig. B) related to the form of the regional structure, a characteristic indicating that the lineation formed contemporaneously with the domes and synforms and is not an earlier feature rotated into parallelism with the younger structures. The lineation and the $S$ and $C$ fabrics in south Ivisârtoq are locally deformed by small-scale crinkles and chevron folds with shallow axes and axial surfaces. The significance of these folds is uncertain, but they may be related to movements on faults (figs 1,2 ).

Brewer et al. (1984) have drawn attention to a suite of amphibolite dykes in Kangilíngua (figs 1,2 ) with rimmed aggregates of feldspar similar to those of $C$ Ameralik dykes. The dykes cut Amîtsoq gneisses, Ameralik dykes (sensu stricto) and younger granitic gneiss (Ivisârtoq granite gneiss; Robertson, 1985). The place of these dykes in the regional chronology was uncertain, but investigations in 1985 have revealed not only more members of the suite in Kangilíngua but also their relative age.

The dykes are medium grained, 0.5-3 m thick and traceable along strike for up to $500 \mathrm{~m}$. Many occupy steep, sinistral shear zones trending north-east broadly parallel to axial surfaces of folds parasitic on the dome-synform system in north-east Ivisârtoq. A few dykes are coincident with axial surfaces. Planar and linear fabrics within the dykes are generally distributed asymmetrically, being more intense on one margin than the other. $S$ fabrics, locally with concordant thin seams or lenticles of pegmatitic neosome, are parallel to dyke boundaries. The linear fabric of hornblende is broadly coaxial with the regional lineation related to the domes and synforms (fig. 2). Concordant sheets of pale biotite granite (sensu lato) with similar $L S$ fabrics occur in some of the amphibolite dykes. The relative thickness of the granite sheets indicates injection after the amphibolite, although their orientation and $L S$ fabrics suggest the acid and basaltic injections were broadly contemporaneous.

Because their geometry and fabrics are identical to those of the numerous sheets of pegmatite and granite coplanar with folds parasitic on the dome-synform system in Kangilingua (Chadwick, 1985), the amphibolite dykes are regarded as having formed contemporaneously with the syntectonic acid injections. Although limited basaltic injections are known to have been associated with the emplacement of the Amitsoq gneisses (Inaluk dykes, Isukasia; Nutman, 1982) and the Nûk gneisses (Intra-Nûk dykes, Buksefjorden; Chadwick \& Coe, 1983), the amphibolite dykes in Kangilíngua appear to be the first recorded examples of basic injections contemporaneous with late Archaean upright structures in the Godthåbsfjord region.

Sheets and small irregular bodies of granite (sensu lato) and pegmatite younger than the Nâk and other gneisses are very common in Ivisârtoq. The large subhorizontal sheets of pegmatite in the Malene outcrops in south Ivisârtoq and some of the steep sheets of pegmatite and foliated granite in the core of SWIS (figs 1,2) may be correlated with the Qorqut granite complex on the grounds of isotopic age data reported by Brown et al. (1981), but other pegmatites in the Malene outcrop which occupy necks of large boudins or the axial surfaces of folds parasitic on the regional synclines (KSS and SWIS; figs 1,2) may be syntectonic like the sheets of pegmatite, granite and amphibolite in Kangilíngua.

Low-angle sheets and irregular intrusions of grey granite (sensu lato), commonly with a spotty texture of quartz and feldspar cored by sphene, magnetite or biotite in Qangátapiluit and south Ivisârtoq (Brewer et al., 1984), have variably intense $S$ or $L S$ fabrics which are parallel to the margins in the sheets, or curve parallel to sinuous contacts of irregular bodies. 
Many of the sheets appear to have been injected into active shear zones, whilst others are cut by shear zones with seams of pegmatite or granite. The irregular bodies may have an outcrop area of a few hundred square metres, whilst others form stockworks of thin, discontinuous sheets and lenses. Small xenoliths of the host gneisses are relatively common. The form of some of the stockworks suggests intrusion was assisted by stoping. The relative age of these granites, in particular the sphene granites in Qangátapiluit, remains equivocal. On the one hand, they might be regarded as parts of stockworks above diapirs associated with the doming, but equally they may be younger than the domes because their fabrics bear no consistent relation to the structures they intrude.

The principal faults in Ivisârtoq (figs 1,2) are part of the complex regional system of fractures outlined by Brewer et al. (1984). Some are marked by mylonites a few metres thick, whilst others appear to be higher level phenomena characterised by more brittle deformation. The principal faults displace the early Proterozoic north-south MD dykes (not shown in figs 1,2 ) but in east Ivisârtoq fracture systems containing thin veneers of epidote appear to be older than steep acid dykes comparable with early Proterozoic acid dykes in Isukasia (KaIsbeek \& Taylor, 1983). An early Proterozoic age is thus indicated for many of the faults in Ivisârtoq. Many faults contain crush zones, quartz and epidote veins and reddened feldspars. The steep fault cutting the Malene rocks in south Ivisârtoq (figs 1,2) is locally rich in sulphides, including pyrite and pyrrhotite. Faults with shallow dip are common in the gneisses of south Ivisârtoq but their role in the regional fracture system is uncertain.

Acknowledgements. I gratefully acknowledge the generous award of an Overseas Field Research Grant from the Royal Society, London, and the practical support and a contribution towards helicopter charter by the Geological Survey of Greenland. I am most grateful to A. A. Garde, S. B. Jensen and R. J. Braithwaite for their help and encouragement. My thanks also go to my colleagues in Exeter and to $\mathrm{C}$. R. L. Friend and A. P. Nutman for discussion and critical comments.

\section{References}

Allaart, J. H., Jensen, S. B., McGregor, V. R. \& Walton, B. J. 1977: Reconnaissance mapping for the 1:500 000 map sheet in the Godthåb-Isua region, southern West Greenland. Rapp. Grønlands geol. Unders. 85, 50-54.

Beech, E. M. \& Chadwick, B. 1980: The Malene supracrustal gneisses of northwest Buksefjorden: their origin and significance in the Archaean crustal evolution of southern West Greenland. Precambrian Res. 11, 329-355.

Berthé, D., Choukroune, P. \& Jegouzo, P. 1979: Orthogneiss, mylonite and non-coaxial deformation of granites: the example of the South Armorican Shear Zone. J. struct. Geol. 1, 31-42.

Brewer, M., Chadwick, B., Coe, K. \& Park, J. F. W. 1984: Further field observations in the Ivisârtoq region of southern West Greenland. Rapp. Grønlands geol. Unders. 120, 55-67.

Brown, M., Friend, C. R. L., McGregor, V. R. \& Perkins, W. T. 1981: The late Archaean Qorqut granite complex of southern West Greenland. J. geophys. Res. 86, 10617-10632.

Chadwick, B. 1981: Field relations, petrography and geochemistry of Archaean amphibolite dykes and Malene supracrustal amphibolites, northwest Buksefjorden, southern West Greenland. Precambrian Res. 14, 221-259.

Chadwick, B. 1985: Contrasting styles of tectonism and magmatism in the Late Archaean crustal evolution of the northeastern part of the Ivisârtoq region, inner Godthåbsfjord, southern West Greenland. Precambrian Res. 27, 215-238. 
Chadwick, B. \& Coe, K. 1983: Descriptive text to the 1:100 000 sheet Buksefjorden 63 V. 1 Nord. Grønlands geol. Unders., 70 pp.

Chadwick, B., Crewe, M. A. \& Park, J. F. W. 1983: Field work in the north of the Ivisârtoq region, inner Godthåbsfjord, southern West Greenland. Rapp. Grønlands geol. Unders. 115, 49-56.

Coe, K. \& Robertson, S. 1984: Contrasting styles of Archaean crustal evolution in parts of southern West Greenland. J. Geodynam. 1, 301-311.

Crewe, M. A. 1984: A textural study of Archaean peridotites; Ujaragssuit nunat, Ivisârtoq region, southern West Greenland. Rapp. Grønlands geol. Unders. 120, 70-74.

Friend, C. R. L. 1976: Field relationships and petrology of leucocratic schists from the Ravns Storø Group near Fiskenæsset. Rapp. Grønlands geol. Unders. 73, 81-85.

Friend, C. R. L. \& Hughes, D. J. 1978: Relict plutonic textures in Archaean ultramafic rocks from the Fiskenæsset region, southern West Greenland; implications for crustal thickness. In Windley, B. F. \& Naqvi, S. M. (edit.) Archaean geochemistry. Developments in Precambrian geology 1, 375-392. Amsterdam: Elsevier.

Friend, C. R. L., Hall, R. P. \& Hughes, D. J. 1981: The geochemistry of the Malene (mid-Archaean) ultramafic-mafic amphibolite suite, southern West Greenland. In Glover, J. E. \& Groves, D. E. (edit.) Archaean geology. Spec. Publ. geol. Soc. Australia 7, 301-312.

Hall. R. P. 1980: The tholeiitic and komatiitic affinities of the Malene metavolcanic amphibolites from Ivisârtoq, southern West Greenland. Rapp. Grønlands geol. Unders. 97, $20 \mathrm{pp}$.

Hall, R. P. 1981: The Archaean geology of Ivisârtoq, inner Godthåbsfjord, southern West Greenland. Unpublished Ph.D. thesis, Committee for National Academic Awards, U.K.

Hall, R. P. \& Friend, C. R. L. 1979: Structural evolution of the Archaean rocks in Ivisârtoq and the neighbouring inner Godthåbsfjord region, southern West Greenland. Geology 7, 311-315.

Hall, R. P. \& Friend, C. R. L. 1983: Intrusive relationships between young and old Archaean gneisses: evidence from Ivisârtoq, southern West Greenland. Geol. Jour. 18, 77-91.

Kalsbeek, F. \& Taylor, P. N. 1983: Anatectic origin of mid-Proterozoic granite dyke in the Isukasia area, West Greenland: $\mathrm{Pb}-\mathrm{Pb}$ and $\mathrm{Rb}-\mathrm{Sr}$ isotope evidence. Rapp. Grønlands geol. Unders. 115, 38-42.

Nutman, A. P. 1982: Further work on the early Archaean rocks of the Isukasia area, southern West Greenland. Rapp. Grønlands geol. Unders. 110, 49-54.

Robertson, S. 1985: Late Archaean crustal evolution in the Ivisârtoq region, southern West Greenland. Unpublished Ph.D. thesis, University of Exeter.

Robertson, S. in press: Evolution of the late Archaean lower continental crust in southern West Greenland. Spec. Publ. geol. Soc. Lond.

Simpson, C. 1985: Deformation of granitic rocks across the brittle-ductile transition. J. struct. Geol. 7, 503-511.

Weaver, B. L., Tarney, J. \& Windley, B. F. 1981: Geochemistry and petrogenesis of the Fiskenaesset anorthosite complex, southern west Greenland: nature of the parent magma. Geochim. cosmochim. Acta 45, 711-725.

Department of Geology,

The University,

Exeter EX4 $4 Q E$,

England. 